Eur. J. Clin. Chem. Clin. Biochem.

Vol. 32, 1994, pp. 733-739

(c) 1994 Walter de Gruyter \& Co. Berlin · New York

\title{
Characterization and Extracorporeal Application of a New Phosphate-Binding Agent
}

\author{
By K. Spengler ${ }^{1}$, H. Follmann ${ }^{1}$, K.-S. Boos ${ }^{2}$, D. Seidel ${ }^{2}$ and F. Maywald ${ }^{3}$ \\ 1 Universität Kassel, Fachbereich Biologie-Chemie, Biochemie, Kassel, Germany \\ ${ }^{2}$ Klinikum Großhadern der Universität München, Institut für Klinische Chemie, München, Germany \\ 3 B. Braun Melsungen AG, Sparte Medizintechnik, Bereich Extrakorporale Blutbehandlung, Melsungen, Germany
}

(Received May 26/July 26, 1994)

Summary: A new phosphate-binding agent which does not cause any severe side effects in vivo was developed by modifying a crosslinked dextran with polynuclear iron(III)oxide-hydroxide. Its particle size ranges from 150 to $300 \mu \mathrm{m}$, and the iron content was about $18 \%$ by dry weight. The oxidation state of iron was characterized by ESCA and Mössbauer spectroscopy. The maximum phosphate binding capacity of the iron(III)oxide-hydroxide-modified dextran was determined with respect to aqueous phosphate solutions, human serum and whole blood. The effects on whole blood count, haemolysis, protein concentration and enzyme activities were examined. In addition, the influence of phosphate concentration, $\mathrm{pH}$ and temperature on the phosphate uptake of the material was determined. The results show that this new adsorbent might provide an alternative to conventional phosphate-binding agents. This paper also describes the first experiments on the therapeutic application of the material in an extracorporeal blood perfusion system for the treatment of hyperphosphataemia during haemodialysis.

\section{Introduction}

In chronic renal failure phosphorus retention and hyperphosphataemia play a major role in the development and maintenance of secondary hyperparathyroidism and osteodystrophy $(1-3)$. Neither an adequate diet nor efficient dialysis are usually sufficient to prevent pathologic phosphate concentrations in the blood (4). Antacids such as $\mathrm{Al}(\mathrm{OH})_{3}$ or $\mathrm{CaCO}_{3}$ possess the capacity to adsorb phosphate. However, antacids presently used for that purpose are quite inefficient in binding phosphate in vivo, although aluminum- or calcium-containing compounds are orally administered in large amounts $(5,6)$. The inefficiency of commonly-used phosphate binders creates a clinical dilemma, since the control of hyperphosphataemia requires increased doses, which result in a higher risk of toxicity. This includes bone disease, aluminum dementia from aluminum containing antacids ( 7 , 8 ), and hypercalcaemia, as well as soft tissue calcification from antacids containing calcium (9). The increased tissue content of aluminum appears to be an important factor in the pathogenesis of dialysis-related encepha- lopathy and osteomalacia. The use of calcium compounds is associated with gastrointestinal problems such as diarrhoea or mild constipation and a high risk of hypercalcaemia. The dosage of magnesium hydroxide as an alternative phosphate binder is limited by the serum magnesium concentration. In addition, this agent alone has proved inadequate for the exact control of serum phosphate (10). Current therapies include reduction of dietary phosphate intake, reduction of phosphate absorption in the intestine by phosphate binding agents, and enhanced removal of phosphate from the body through more efficient dialysis techniques. The recommended intake of phosphate should not exceed $32 \mathrm{mmol}(1000 \mathrm{mg}$ P) per day in adults and should be reduced for children according to their age. With highly specialized diets, the intake of phosphorus can be reduced to less than 16 mmol (500 mg P) per day (11). In patients with mildly increased serum phosphate concentrations, haemodialysis removes about $8 \mathrm{mmol}(252 \mathrm{mg} \mathrm{P}$ ) of phosphate per day with three treatments per week. Continuous ambulatory peritoneal dialysis even removes about $10 \mathrm{mmol}$ 
(324 mg P) per day (12). These rates of removal, however, are still insufficient. Hence, most patients with end-stage renal failure require phosphate binders.

Recently we developed a novel phosphate-binding agent by coupling polynuclear iron(III) oxide-hydroxide to crosslinked dextran (13). In addition to its oral application, this material has the potential to serve as a phosphate adsorbent in extracorporeal perfusion systems for the treatment of hyperphosphataemia.

\section{Materials and Methods}

\section{Preparation of phosphate adsorbent}

Starting material for the preparation of an insoluble iron(III)oxidehydroxide porous support was the crosslinked dextran Dormagel $\mathrm{N}$ $25 \mathrm{C}^{\mathrm{TM}}$ (Pfeifer and Langen, Dormagen, Germany). Dormagel ${ }^{\mathrm{TM}}$ is a spherical, neutral, soft gel cross-linked by epichlorhydrin. The molecular cut-off of the unmodified material corresponds to $M_{\mathrm{r}}$ $=6000$, and the particle size is $150-300 \mu \mathrm{m}$. The $\mathrm{pH}$ stability ranges from 2 to 12, and the swelling capacity is $4-6 \mathrm{ml} / \mathrm{g}$.

For chemical modification according to 1.c. (13) the material was suspended in a $50 \%$ solution of $\mathrm{FeCl}_{3} \cdot 6 \mathrm{H}_{2} \mathrm{O}$. This mixture was then added under vigorous stirring to $1 \mathrm{~mol} / 1$ sodium hydroxide solution. The modified gel beads were collected by filtration and washed with water to neutrality. Sterilization was carried out at a temperature of $121^{\circ} \mathrm{C}$ according to $\mathrm{F}_{0} 15$ conditions using an autoclave (type GETING GEV 112) (14).

\section{Test solutions}

Standardized phosphate solution: $10 \mathrm{mmol} / 1 \mathrm{NaCl}, 4 \mathrm{mmol} / 1 \mathrm{KCl}$, $0.5 \mathrm{mmol} / 1 \mathrm{Na}_{2} \mathrm{SO}_{4}, 1.6 \mathrm{mmol} / 1 \mathrm{Na}_{2} \mathrm{HPO}_{4} \cdot 2 \mathrm{H}_{2} \mathrm{O}, 1.6 \mathrm{mmol} / \mathrm{l}$ $\mathrm{NaH}_{2} \mathrm{PO}_{4} \cdot 2 \mathrm{H}_{2} \mathrm{O}(\mathrm{pH}$ 7.4).

Standardized calcium solution: $50 \mathrm{mmol} / \mathrm{l}$ Tris, $2.5 \mathrm{mmol} / \mathrm{CaCl}$ - $2 \mathrm{H}_{2} \mathrm{O}, 10 \mathrm{mmol} / \mathrm{l} \mathrm{NaCl}, 4 \mathrm{mmol} / \mathrm{l} \mathrm{KCl}, 0.5 \mathrm{mmol} / \mathrm{l} \mathrm{Na}{ }_{2} \mathrm{SO}_{4}(\mathrm{pH}$ 7,4).

Blood and plasma: Fresh blood from pigs was obtained from the slaughter house in Melsungen and human blood was provided by the DRK blood bank, Kassel. For stabilization, heparin (6000 IU/l) was added. The blood was centrifuged for $10 \mathrm{~min}$ at $4500 \mathrm{~min}^{-1}$ to separate blood cells from plasma.

\section{Determination of enzymes and electrolytes}

Enzyme activities of glutamate oxaloacetate transaminase, glutamate pyruvate transaminase, lactate dehydrogenase, and alkaline phosphatase were determined according to standard methods, described by Rick (15). Phosphate, calcium, magnesium, iron, and protein concentrations in serum, plasma or aqueous solutions were photometrically determined according to standard protocols (1618).

The iron content of the adsorbent was determined by atomic absorption (AAS) (19), and its phosphate concentration by inductively coupled plasma spectroscopy (ICP) (20).

\section{Physical characterization}

Scanning electron microscopy of the adsorbent was performed on a SEM XS 40 (ABT, Japan) at $20 \mathrm{kV}$. The magnification for the uncoated and the modified dextran beads was in the range of $100-$ 3000-fold. Electron micrographs were taken with an Asanuma Camera (Mechanical Laboratory \& Co, Japan) using a Polaroid
Film Type 52 (400 ASA/27 DIN). ESCA (electron spectroscopy for chemical analysis), Mössbauer and magnetic measurements were kindly performed by Drs. J. Knecht and J. Pebler, Fachbereich Chemie, University of Marburg.

\section{In vitro perfusion experiments}

In vitro tests with standard solutions, plasma, or blood were carried out as follows. Glass columns (Bio-Rad, $120 \times 10 \mathrm{~mm}$ ) were packed with $3 \mathrm{ml}$ of the adsorbent and equilibrated with Tris buffer $\mathrm{pH}$ 7.4. Standard phosphate solution or plasma was pumped through the columns by means of a roller pump (Infusomat, $B$. Braun Melsungen AG) at a flow rate of $1 \mathrm{ml} / \mathrm{min}$. After collection of $4 \mathrm{ml}$ pre-eluate, samples were drawn from the eluate at various time intervals. Phosphate, iron, calcium, glucose, heparin, and enzymes were determined in the samples. For the analysis of plasma the reservoir was kept in a shaking bath at $37^{\circ} \mathrm{C}$.

To determine the maximal binding capacity, aqueous phosphate solution, blood or plasma was circulated for $18 \mathrm{~h}$ at a rate of $1 \mathrm{ml}$ min through a column containing $3 \mathrm{ml}$ adsorbent. The material was then washed with $100 \mathrm{ml}$ distilled water to remove unbound phosphate, dried at $60^{\circ} \mathrm{C}$, and analysed for phosphate as described above.

For adsorption experiments with blood, a cylindrical Makrolon ${ }^{\mathrm{TM}}$ cartridge (volume: $250 \mathrm{ml}$ ) was used. The column inlet and outlet were closed by sieves with a mesh size of $94 \mu \mathrm{m}$. EDTA-stabilized blood $(500 \mathrm{ml})$ was circulated through the cartridge at a flow rate of $100 \mathrm{ml} / \mathrm{min}$. The blood reservoir was kept in a shaking bath at $37^{\circ} \mathrm{C}$.

\section{In vivo perfusion tests}

In vivo experiments were carried out with locally anaesthetized female sheep in the laboratory of the Experimental Surgery department (B. Braun Melsungen AG) according to an officially licensed protocol. Cartridges $(250 \mathrm{ml})$ were slurry-packed with adsorbent and integrated in a dialysis circulation unit (HD secura, B. Braun Melsungen AG). Equilibration of the adsorbent and prewashing of the tubing system was carried out by circulating with $9 \mathrm{~g} / \mathrm{l}$ sodium chloride solution. A conventional dialysis solution (acetate concentrate, $35 \mathrm{mmol} / \mathrm{l}$ ) was used. To prevent fibrin clotting during therapy, heparin $(10000 \mathrm{IU} / \mathrm{h})$ was administered to the sheep.

\section{Results}

\section{Characterization of the adsorbent}

Reaction of the insoluble, crosslinked dextran matrix with a concentrated $\mathrm{FeCl}_{3}$ solution at high $\mathrm{pH}$ led to an iron uptake of $160-210 \mathrm{~g} / \mathrm{kg}$ under our standard reaction conditions. A stable product was obtained after washing with deionized water to neutrality. Drying, heat sterilization, prolonged passage of phosphate solutions, or contact with blood did not result in any leaching or loss of iron from the material. Although the uniform surface of the untreated gel beads became rough and vaulted in the iron-coated spheres (fig. 1) the material could without difficulty be handled in flow-through columns or cartridges.

X-ray diffraction indicated the complete absence of crystalline structures in the solid. The binding energies of iron and oxygen in the compound, determined by X- 

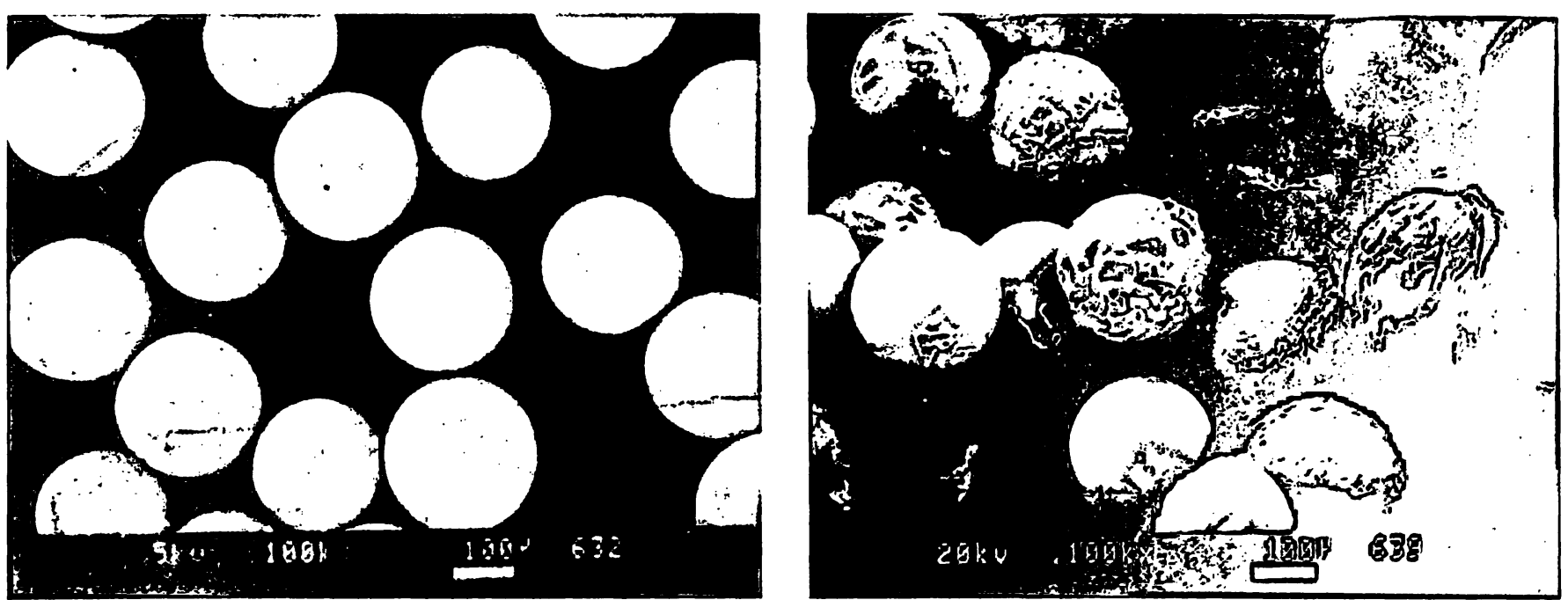

Fig. 1 Scanning electron micrographs of dextran (Dormagel N25C) adsorbent. Left: Unmodified.

Right: Iron(IIl)oxide-hydroxide-modified (Fe: $188 \mathrm{~g} / \mathrm{kg}$ ). Magnification, 100 -fold.

ray photoelectron spectroscopy (ESCA), were $710.5 \mathrm{eV}$ $\left(\mathrm{Fe}_{2 \mathrm{P} 3 / 2}\right)$ and $535.4 \mathrm{eV}\left(\mathrm{O}_{1 \mathrm{~S}}\right)$, respectively, in close agreement with the values found in $\mathrm{Fe}(\mathrm{OH})_{3}$ and other reference compounds (21). Mössbauer and magnetic susceptibility measurements revealed the presence of high-spin $\mathrm{Fe}^{3+}$ ions in a slightly distorted environment, and an effective magnetic moment of $\mu_{\text {eff }}=5.9 \mu_{\mathrm{B}}$. All these data confirm that the oxidation state of the metal in the iron-modified dextran is exclusively + III.

\section{Phosphate adsorption characteristics}

Uptake of phosphate from a standard solution is shown in figure 2. Iron-dextran complexes with an iron content between 190 and $210 \mathrm{~g} / \mathrm{kg}$ revealed the highest phos-

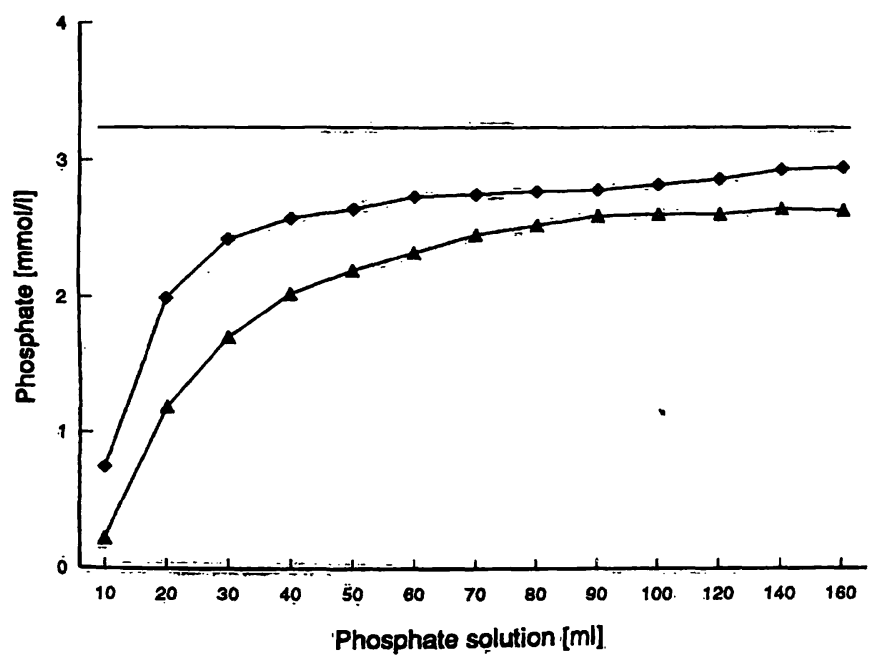

Fig. 2 Removal of phosphate from a standard solution. Columns packed with $3 \mathrm{ml}$ of iron-dextran adsorbent (iron: $188 \mathrm{~g} / \mathrm{kg}$ ) were perfused at $1 \mathrm{ml} \cdot \mathrm{min}^{-1}$ flow rate and the phosphate content of the eluate was determined. The horizontal line represents the initial concentration $\left(P_{i}, 100 \mathrm{mg} / \mathrm{l}\right)$. $\Delta$ : Dried adsorbent, not sterilized. $\bullet$ : Dried material sterilized at $121^{\circ} \mathrm{C}$.
Tab. 1 Iron content and phosphate adsorption capacity of irondextran complexes.

\begin{tabular}{lllll}
\hline $\begin{array}{l}\text { Product } \\
\text { No. }\end{array}$ & $\begin{array}{l}\text { Preparation } \\
\text { conditions }\end{array}$ & $\begin{array}{l}\text { Iron } \\
\text { content } \\
(\mathrm{g} / \mathrm{kg})\end{array}$ & $\begin{array}{l}\text { Phosphate } \\
\text { adsorption } \\
(\mathrm{mmol} / \mathrm{l})\end{array}$ & $\begin{array}{l}\text { Phos- } \\
\text { phorus } \\
\text { content } \\
(\mathrm{g} / \mathrm{kg})\end{array}$ \\
\hline 4 & reaction at $\mathrm{pH} 6$ & 84 & 56 & 4.0 \\
5 & standard & 157 & 71 & 5.1 \\
3 & standard & 188 & 74 & 5.3 \\
8 & standard & 199 & 84 & 6.0 \\
2 & standard & 203 & 88 & 6.3 \\
1 & standard & 211 & 89 & 6.4 \\
6 & $\mathrm{FeCl}_{3}$ repeated & 255 & 85 & 6.1 \\
7 & $\mathrm{FeCl}_{3}$ repeated & 293 & 85 & 6.1 \\
\hline
\end{tabular}

phate binding capacity (tab. 1). Higher amounts of iron, produced by repeated treatment of the adsorbent in $\mathrm{FeCl}_{3}$ solution, did not raise the phosphate binding capacity. In equilibrium binding experiments, sterile adsorbents coated with $210 \mathrm{~g} / \mathrm{kg}$ iron typically bound 250 mmol (7.7 g) $P_{i}$ per $\mathrm{kg}$ or $90 \mathrm{mmol}(2.6 \mathrm{~g}) P_{i}$ per litre adsorbent. These values were obtained by equilibrating $3 \mathrm{ml}$ of sterilized adsorbent in a column for $18 \mathrm{~h}$ with $500 \mathrm{ml}$ circulating phosphate standard solution, followed by removal of unbound inorganic phosphate by washing the column with $50 \mathrm{ml}$ distilled water. Absorption of phosphate from an aqueous solution onto the iron-dextran complex could also be monitored by ${ }^{31} \mathrm{P}$ NMR (not shown).

The phosphate adsorption capacity was generally reduced about $30 \%$ after heat sterilization (fig. 2). On the other hand, heat sterilization appears to lead to a stabilized iron(III) oxide-hydroxide modified dextran at acidic $\mathrm{pH}$ values. Thus, the sterilized adsorbent does not liberate iron even around $\mathrm{pH} 2$. 
Perfusion of $3 \mathrm{ml}$ adsorbent $(950 \mathrm{mg}$ dry weight, iron content $157 \mathrm{~g} / \mathrm{kg}$ ) with $100 \mathrm{ml}$ human plasma resulted in the binding of $2.04 \mathrm{~g}$ phosphorus per litre gel which corresponds to a $74 \%$ reduction of the phosphate content (fig. 3). No alterations of the protein and iron(III) concentration, or of distinct enzyme activities were observed during the treatment. The profile of the elimination curve shows that additional phosphate can be adsorbed when higher blood phosphate concentrations are present.

Investigation of the haemocompatibility of the adsorbent in a $250 \mathrm{ml}$-cartridge showed that the phosphate concentration of circulating whole blood decreased from 1.1 $\mathrm{mmol} / \mathrm{l}$ to $0.09 \mathrm{mmol} / \mathrm{l}\left(3.4 \mathrm{mg} / \mathrm{dl}\right.$ to $\left.0.3 \mathrm{mg} / \mathrm{dl} \mathrm{P}_{\mathrm{i}}\right)$. At a flow rate of $100 \mathrm{ml} / \mathrm{min}$, a pressure of $80 \mathrm{mbar}$ was built up. Even after 25 circulations the material did not induce haemolytic reactions, and there were no significant alterations in common blood quantities as shown in table 2.

\section{Elimination of calcium ions}

The behaviour towards calcium ions was determined by perfusing the adsorbent in a $3 \mathrm{ml}$ column with $100 \mathrm{ml}$ of human serum, heparinized plasma or standardized calcium solution (fig. 4). Calcium was only bound to the adsorbent in the presence of phosphate but not in phosphate-free solution. A molar ratio of calcium and phosphate elimination of approximately $1: 1$ was reached when both concentrations were varied.

\section{In vivo experiments}

The iron(III)oxide-hydroxide dextran adsorbent was tested in extracorporeal apheresis experiments with sheep. Laboratory data are reported in table 3. The aim of these tests was to investigate functional aspects such

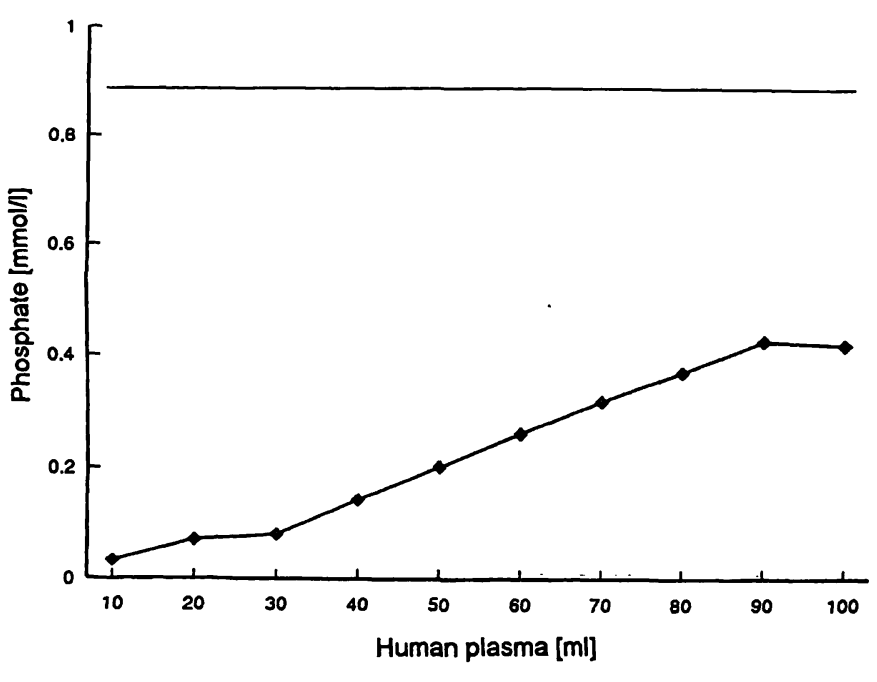

Fig. 3 Elimination of phosphate from $100 \mathrm{ml}$ human plasma (initial P content, $2.8 \mathrm{mg})$. Conditions as in Fig. 2. as handling, flow rate, pressure, and the influence on important quantities such as haemocompatibility, whole blood count, and the concentrations of phosphate, calcium and iron. The application of the adsorbent caused an efficient and significant decrease of the postcartridge phosphate concentration from $1.93 \mathrm{mmol} / \mathrm{l}(6.0$ $\mathrm{mg} / \mathrm{dl})$ to $0.06 \mathrm{mmol} / 1(0.2 \mathrm{mg} / \mathrm{dl}) \mathrm{P}_{\mathrm{i}}$ at the end of treatment $(1 \mathrm{~h}$ dialysis). There was neither an increase in the iron nor a decrease in the calcium concentration of the blood during treatment with conventional dialysis solutions containing calcium. By appropriate dosage of heparin, the flow rate and pressure could be kept at normal levels without inducing haemolysis or significant alterations of the blood cells. Only thrombocytes were reduced during treatment. This was possibly due to some fibrin clotting which was not observed in in vitro experiments.

\section{Discussion}

Patients with kidney diseases, especially those with chronic renal failure, who have been on haemodialysis for a long time, often have symptoms associated with highly elevated concentrations of inorganic phosphate in the blood. Large amounts of phosphate above normal levels $(0.6-1.3 \mathrm{mmol} / \mathrm{l})$ result in a decrease of calcium ion concentration which in turn induces the parathyroid to secrete an excess amount of parathyroid hormone. The hormone increase and the inability of the diseased kidney to hydroxylate 25-hydroxycholecalciferol to the active forms of vitamin $\mathrm{D}$ are the principal biochemical factors underlying most of the related symptoms (22, 23). In the case of chronic renal failure the filtration rate of glomeruli is less than $8-10 \mathrm{ml} / \mathrm{min}$. Pathological phosphate concentrations ranging between 2.25 and $3 \mathrm{mmol} / \mathrm{l}$ normally decrease to $1.3-1.6 \mathrm{mmol} / \mathrm{l}$ after haemodialysis (24). In this context, it has recently been shown that extracorporeal elimination of phosphate is more effective using standard dialysers than high-fluxdialysers (T. Eisenhauer, $C$. Ronco, unpublished). This effect is due to the limited phosphate concentration in the blood. Thus, the intravascular phosphate concentration rather than the clearance seems to be rate-limiting. The phosphate clearance, for example of the Diacap capillary dialyser (B. Braun, Melsungen, Germany) lies between 93 and $150 \mathrm{ml} / \mathrm{min}$ when pumping blood at 200 $\mathrm{ml} / \mathrm{min}$ and dialysis solution at $500 \mathrm{ml} / \mathrm{min}$.

The phosphate intake of a patient is $32 \mathrm{mmol}$ per day or about $224 \mathrm{mmol}$ per week. During one dialysis session about $32 \mathrm{mmol}$ phosphate are normally eliminated (4). These rates of removal are insufficient to prevent hyperparathyroidism. The surplus of about 130 mmol phosphate per week has to be additionally eliminated. Hence, 
Tab. 2 Blood count and erythrocyte characteristics during perfusion of iron-dextran phosphate adsorbent with human blood.

\begin{tabular}{|c|c|c|c|c|c|c|c|c|c|c|c|}
\hline \multirow[t]{2}{*}{ Quantity } & \multicolumn{11}{|c|}{ Number of passages } \\
\hline & 0 & 2 & 4 & 6 & 8 & 10 & 12 & 16 & 20 & 24 & 25 \\
\hline Leukocytes $\left(10^{\circ} /\right)$ & 4.9 & 5.1 & 5.0 & 5.0 & 4.9 & 5.2 & 4.9 & 5.2 & 4.9 & 4.7 & 4.9 \\
\hline Erythrocytes $\left(10^{12} / 1\right)$ & 4.4 & 4.5 & 4.4 & 4.4 & 4.5 & 4.4 & 4.5 & 4.3 & 4.3 & 4.3 & 4.5 \\
\hline Haemoglobin $(\mathrm{g} / \mathrm{l})$ & 125 & 126 & 126 & 126 & 127 & 126 & 127 & 124 & 124 & 125 & 124 \\
\hline Haematocrit (fraction) & 0.392 & 0.399 & 0.395 & 0.391 & 0.395 & 0.390 & 0.390 & 0.375 & 0.374 & 0.373 & 0.371 \\
\hline $\operatorname{MCV}(\mathrm{fl})$ & 89.7 & 89.0 & 88.9 & 88.4 & 88.3 & 87.8 & 87.4 & 86.9 & 86.7 & 86.8 & 86.5 \\
\hline $\mathrm{Hb}_{\mathrm{E}}(\mathrm{pg})$ & 28.5 & 38.0 & 26.3 & 28.5 & 28.5 & 28.4 & 28.5 & 28.8 & 28.7 & 26.7 & 29.0 \\
\hline $\mathrm{MCHC}(\mathrm{g} / \mathrm{l})$ & 318 & 315 & 318 & 322 & 324 & 324 & 324 & 331 & 331 & 330 & 335 \\
\hline Thrombocytes $\left(10^{9} / 1\right)$ & 264 & 273 & 270 & 257 & 269 & 269 & 267 & 272 & 266 & 256 & 270 \\
\hline Lymphocytes (\%) & 29 & 30 & 32 & 33 & 30 & 30 & 35 & 27 & 27 & 31 & 30 \\
\hline Monocytes (\%) & 3 & - & 1 & 3 & 5 & 5 & 4 & 4 & 4 & 5 & 6 \\
\hline Segm. granulocytes (\%) & 62 & 66 & 63 & 59 & 63 & 63 & 53 & 61 & 65 & 60 & 62 \\
\hline Eosinophiles (\%) & 3 & 4 & 2 & 1 & 1 & 1 & 3 & 8 & 4 & 4 & 2 \\
\hline Basophiles (\%) & 1 & - & - & 1 & 1 & 1 & - & - & - & - & - \\
\hline
\end{tabular}

A cartridge containing $250 \mathrm{ml}$ phosphate adsorbent was perfused at $100 \mathrm{ml} \cdot \mathrm{min}^{-1}$ under recirculating conditions with $500 \mathrm{ml} \mathrm{hu}$ man blood containing $7 \mathrm{mmol} / \mathrm{EDTA}$.

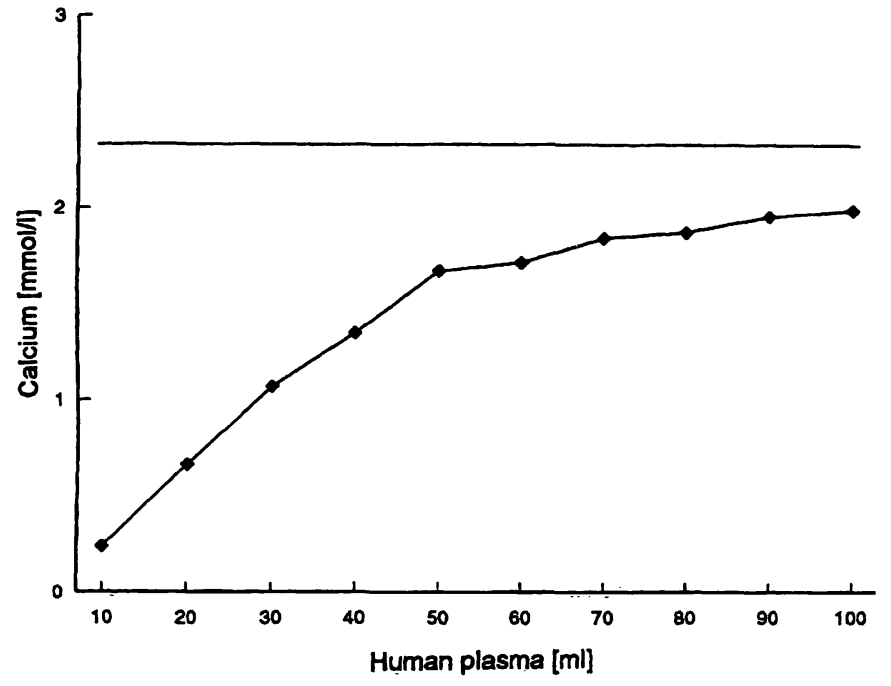

Fig. 4 Elimination of calcium from $100 \mathrm{ml}$ human plasma (initial Ca content, $9.35 \mathrm{mg}$ ) concomitant with phosphate removal (cf. fig. 3).

Tab. 3 Electrolyte concentrations in sheep blood during an extracorporeal treatment with iron-dextran complex.

\begin{tabular}{lllllll}
\hline Electrolyte & \multicolumn{2}{l}{ Time (min) } \\
\cline { 2 - 7 } & 0 & 15 & 30 & 45 & 60 & 75 \\
\hline $\mathrm{P}(\mathrm{mmol} / \mathrm{l})$ & 1.94 & 0.03 & 0.03 & 0.13 & 0.06 & 0.06 \\
$\mathrm{Fe}(\mu \mathrm{mol} / \mathrm{l})$ & 2.65 & 2.63 & 2.75 & 2.79 & 2.40 & 2.72 \\
$\mathrm{Ca}(\mathrm{mmol} / \mathrm{l})$ & 2.52 & 2.87 & 2.54 & 2.64 & 3.29 & 2.85 \\
\hline
\end{tabular}

Blood was pạssed through a cartridge containing $250 \mathrm{ml}$ of phosphate adsorbent; flow rate, $70-90 \mathrm{ml} / \mathrm{min}$.

most patients with end-stage renal failure and many with moderate to marked renal insufficiency require phosphate binders. Their application is necessary to avoid
MCV = Mean corpuscular volume

$\mathrm{Hb}_{\mathrm{E}}=$ Haemoglobin content per erythrocyte

$\mathrm{MCHC}=$ Mean corpuscular haemoglobin concentration

skeletal pain, changes in bone mineralization, spontaneous fractures, and calcium phosphate-like deposits in soft tissues and blood vessels $(25,26)$. In recent years it has been reported that the most seriously intoxicated patients had been treated with dialysing fluid containing high concentrations of aluminum and phosphate binders containing aluminum (27-29). The dialysis dementia syndrome was related to the increased concentration of aluminum in the plasma and in the brain tissue $(30,31)$. For that reason many authors propagated the oral application of aluminum-free compounds such as calcium carbonate or calcium acetate $(32,33)$. However, medication with the latter is associated with gastro-intestinal problems and a high risk of hypercalcaemia (10).

From these considerations it follows that a more effective and safer treatment of hyperphosphataemia can be achieved by extending the total dialysis time and by the optional application of aluminum-free phosphate binders. Prolonging dialysis time, however, is not applicable as it additionally stresses the patient. Instead, the desired systemic reduction of phosphate should be achieved by using, in addition to and simultaneously with conventional haemodialysis, an adsorbent which specifically removes the excess phosphate. To be clinically useful, such an adsorbent has to be integrated into the extracorporeal perfusion system and must be capable of eliminating phosphate directly from whole blood. Extracorporeal removal of excess inorganic phosphate is especially of interest for patients who refuse phosphatelowering medication because of personal discomfort. For a potentially chronic application such a procedure must be free of even minor side effects. In addition, it should permit a blood flow of at least $100 \mathrm{ml} / \mathrm{min}$. 
We therefore recently developed a new phosphate binding agent (13). A porous, highly crosslinked and insoluble dextran was complexed with polynuclear iron oxidehydroxide $(\mathrm{FeOOH})$ centres. With the exception of a non-porous agarose chromatography support described by Hjerten (34), only soluble complexes between iron hydroxide and mono- and polysaccharides have previously been prepared $(35,36)$. Such complexes, e.g. with polymaltose (Ferrum-Hausmann ${ }^{\mathrm{TM}}$ ), are used for the therapeutic treatment of iron deficiency anaemias in humans and animals $(37,38)$. Structural studies on soluble iron oxide-hydroxide complexes showed that they form chainlike, polynuclear condensation products (39) and that iron is present as tetragonal $\beta-\mathrm{FeOOH}(40)$.

Structure characterization of the newly synthesized, amorphous, insoluble iron-dextran complexes is less complete. Nevertheless, the ESCA and Mössbauer spectra confirm that only high-spin ferric irons with oxygen ligands (sugar $\mathrm{OH}$ groups, water, hydroxide ions, $\mu$-oxo bridges) are present. The most typical iron mass proportion of about $200 \mathrm{~g} / \mathrm{kg}$ found in the dry material suggests that each iron(III) centre is statistically coordinated to one glucose moiety (glucose $\cdot \mathrm{Fe}(\mathrm{OH})_{3}, \mathrm{Fe}=$ $195 \mathrm{~g} / \mathrm{kg}$ ). In fact, the magnetic susceptibility and its temperature dependence, measured in the range from 4 to $300 \mathrm{~K}$, are very similar to a soluble, stoichiometric Fe-glucose complex (35).

A few reports describe the interaction of phosphate with iron-containing compounds $(34,37,41,42)$. Addition of phosphate, even in small amounts, may lead to strong effects, for example increased viscosity in iron-polymaltose solutions (37). FeOOH-modified non-porous agarose has been saturated with phosphate and used in this form as ion exchanger for the chromatography of proteins (34).

\section{References}

1. Bricker, N. S., Slatopolsky, E., Preiss, E. \& Aviolo, L. V. (1969) Calcium phosphorus and bone renal disease and transplantation. Arch. Intern. Med. 123, 543-553.

2. Rubini, M. E., Coburn, J. W., Massry, S. G. \& Shinaber, J. H. (1969) Renal osteodystrophy - Some therapeutic considerations relative to long-term dialysis and transplantation. Arch. Intern. Med. 124, 663-669.

3. Coburn, J. E. \& Salusky, I. B. (1989) Control of serum phosphorus in uremia. New England J. Med. 320, 1140-1142.

4. Günther K., Sperschneider, H., Stein, G. \& Gaida, P. (1990) Phosphatrestriktion bei optimaler Eiweißzufuhr. Dial. J. 31, 29-34.

5. Ramirez, J. A., Emmett, W., White, M. G., Fathi, N., Ana Cas, Morawaski, S. G. \& Fordtran, J. S. (1986) The absorption of dietary phosphorus and calcium in haemodialysis-patients. Kidney Int. 30, 753-759.
The adsorbent described here is, to our knowledge, the first one that specifically removes inorganic phosphate and which fulfils the criteria for an application in an extracorporeal blood perfusion system. The high binding capacity of the adsorbent guarantees an efficient elimination of phosphate during haemodialysis. The pathological excess of about $130 \mathrm{mmol}$ of phosphate per week in patients with end-stage renal failure, for example, would be eliminated during the common three dialysis sessions by an additional, integrated phosphate adsorption apheresis using a cartridge packed with $450 \mathrm{ml}$ of the new adsorbent.

On-line apheresis has the extra advantage that it can be precisely controlled by adjusting the cartridge size (i. e. total phosphate binding capacity) to the blood volume. Material costs can be significantly reduced by repeated regeneration and re-use of the adsorbent. In this context it was shown that regeneration by a simple treatment with $\mathrm{NaOH}$ did not cause a decrease of the phosphate binding capacity. The described in vivo experiments with sheep revealed no side effects. Concomitant calcium depletion can be compensated by dialysis. Ideally, it may be expected that oral phosphate binders can be avoided and no other measures have to be taken.

In conclusion, the newly developed iron(III) oxide-hydroxide modified dextran is suitable for the selective elimination of inorganic phosphate from whole blood. The excellent phosphate elimination capacity and blood compatibility make it attractive for the extracorporeal treatment of hyperphosphataemia in acute and chronic renal failure.

\section{Acknowledgement}

This work was made possible by a grant from the B. Braun Melsungen AG. The authors thank Professor $F$. von der Haar, Professor T. Eisenhauer and Dr. C. Ronco for helpful discussions and the B. Braun laboratories for making facilities available.

6. Yokel, R. A. (1989) Benefit vs. risk of oral aluminum forms: Antacid and phosphate binding vs. absorption. Drug Chem. Toxicol. 12, 277-286.

7. Bauman, J. L. (1987) Aluminum-induced bone disease in renal failure. Hospital Ther. 87, 48-55.

8. De Broe, M. E., D'Haese, P. C., Van De Vyver, F. L. \& Lamberts, L. V. (1991) Aluminiuminduzierte Osteopathie bei Patienten mit chronisçher Niereninsuffizienz. Nieren-Hochdruckkrankh. 20, 311-316.

9. Ritz, E. \& Bommer, J. (1980) Störungen des Calcium- und Phosphatstoffwechsels bei Niereninsuffizienz. In: Chronische Niereninsuffizienz, pp. 398-407, Verlag Chemie, Weinheim.

10. Sheikh, M. S., Maguire, J. A., Emmett, M., Santa Ana, C: A., Nicar, M. J., Schiller, L. R. \& Fordtran, J. S. (1989) Reduction of dietary phosphorus absorption by phosphorus binders. J. Clin. Invest. 83, 66-73. 
11. Barsotti, G., Morelli, E. \& Guiducci, A. (1982) Reversal of hyperparathyroidism in severe uremics following very lowprotein and low-phosphate diet. Nephron 30, 310-313.

12. Herez, G. \& Coburn, J. W. (1987) Prevention of phosphate retention and hyperphosphatemia in uremia. Kidney Int. (Suppl.) 22, 215-220.

13. Boos, K.-S., Seidel, D., Rauh, A., Spengler, K. \& Henke, G. (1992) Verfahren zur selektiven Elimination von anorganischem Phosphat aus Flüssigkeiten mittels polynuclearen Metalloxidhydroxid-modifizierten Adsorptionsmaterialien. German Pat. Appl. P41 39 442.2.

14. Food and Drug Administration (FDA) (1976) Federal Register 41 , No. 106

15. Rick, W. (1990) Klinische Chemie und Mikroskopie. 6. Auflage. pp. 287-294. Springer Verlag Berlin, Heidelberg, New York.

16. Thomas, I. (1992) Labor und Diagnose. 4. Auflage, pp. 50, $121,136,342,358,390$, Medizinische Verlagsgesellschaft, Marburg.

17. Empfehlungen der Deutschen Gesellschaft für klin. Chemie (1972) Z. Klin. Chem. Klin. Biochem. 10, 182.

18. Richterlich, R. (1971) Klinische Chemie - Theorie und Praxis. 3. erw. Auflage, p. 228. Karger Verlag, Basel.

19. Marr, I. L., Cresser, M. S. \& Ottendorfer, L. J. (1983) Analytische Chemie für die Praxis - Umweltanalytik (Hulpke, H., Hartkamp, H. \& Tölg, G., eds.) Thieme-Verlag, Stuttgart, pp. 243-251.

20. Welz, B. (1981) Atomspektroskopische Spurenanalytik. Verlag Chemie, Weinheim.

21. Carver, J. C., Schweitz, G. K., Carlson, T. A. (1972) Use of $\mathrm{X}$-ray photoelectron spectroscopy to study bonding in $\mathrm{Cr}, \mathrm{Mn}$, $\mathrm{Fe}$ and Co compounds. J. Chem. Phys. 57, 973.

22. Heckmann, C., Rudorff, K.-H. \& Saueressig, U. (1991) Klinische Problematik des sekundären Hyperparathyreoidismus. Nephrologisches Jahresgespräch 1991, Kassel.

23. Ritz, E., Matthias, S. \& Reichel, H. (1991) Therapeutische Strategien beim sekundären (renalen) Hyperparathyreoidismus. Nephrologisches Jahresgespräch 1991, Kassel.

24. Henning, H. V. (1988) Therapie mit Phosphatbindern bei chronischen Dialysepatienten. Dial. J. 22, 10-16.

25. Henning, H. V. \& Fuchs, C. (1984) Renale Osteopathie. Nieren-Hochdruckkrankh. 13, 235-253.

26. Croucher, P. I., Wright, C. D. P., Garrhan, N. J., Kudlac, H., Williams, A. J. \& Compston, J. E. (1992) Characteristics of trabecular bone ressorption cavities in patients with chronic renal failure. Bone Mín. 16, 139-147.

27. Mahurkar, S. D., Smith, E. C., Mamdani, B. H. \& Dunea, G. (1978) Dialysis dementia. The Chicago experience. J. Dial. 2, 447-458.
28. Rosas, V. V., Port, F. K. \& Rutt, W. M. (1978) Progressive dialysis encephalopathy from dialysate aluminum. Arch. Intern. Med. 138, 1375-1377.

29. Walker, G. S., Aaron, J. E., Peacock, M., Robinson, P. J. A. \& Davison, A. M. (1982) Dialysate aluminum concentration and renal bone disease. Kidney Int. 21, 411-415.

30. Alfrey, A. C., Le Gendre, G. R. \& Kachny, W. D. (1976) The dialysis encephalopathy syndrome: Possible aluminum intoxication. New England J. Med. 294, 184.

31. Sideman, S. \& Manor, D. (1982) The dialysis dementia syndrome and aluminium intoxication. Nephron $1,1-10$.

32. Schaefer, K. (1993) Alternative phosphate binders: An update. Nephrol. Dial. Transplant. 1, 35-39.

33. Mai, M. L., Emmett, M., Sheikh, M. S., SAnta Ana, C. A., Schiller, L. \& Torattran, J. S. (1989) Calcium acetate, an effective phosphorus binder in patients with renal failure. Kidney Int. 36, 690-695.

34. Hjerten, S., Zelikmann, I., Lindenberg, J., Liao, J.-I., Eriksson, K.-O. \& Mohammad, J. (1984) High-performance adsorption chromatography of proteins on deformed non-porous agarose beads coated with insoluble metal compounds. J. Chromat. 481, 175-186.

35. Pulla Rao, C., Geetha, K. \& Raghavan, M. S. S. (1994) Fe(III) complexes of D-glucose and D-fructose. BioMetals 7, 25-29.

36. Rich, H. W., Hegetschweiler, K., Streit, H. M., Emi, 1. \& Schneider, W. (1991) Mononuclear, oligonuclear, and polynuclear iron(III)complexes with polyalcohols formed in alkaline aqueous media. Inorg. Chim. Acta 187, 9-15.

37. Müller, A. (1967) Makromolekulare Eisen(III)-HydroxidKomplexe. Arzneim. Forsch. 17, 921-931.

38. Schwengers, D. (1990) Water soluble iron dextran and a process for its manufacture. United States Patent, No. 4. 927. 756.

39. Yang, C.-Y., Bryan, A. M., Theil, E. C., Sayers, D. E. \& Browen, L. H. (1986) Structural variations in soluble iron complexes of models for ferritin. J. Inorg. Biochem. 28, 393-405.

40. Marshall, P. R. \& Rutherford, D. (1971) Physical investigations on colloidal iron-dextran complexes. J. Colloid Interface Sci. $37,390-402$

41. Lijkiema, L. (1980) Interactions of orthophosphate with iron(III) and aluminum hydroxides. Environm. Sci. Technol. $14,537-541$.

42. Thole, S. (1992) Einfluß der Wassermatrix auf die Adsorption von Phosphat an Eisenoxidhydratschlämmen. Vom Wasser 79, $313-321$.

Prof. Dr. Hartmut Follmann

Fachbereich Biologie-Chemie der Universität

Heinrich-Plett-Straße 40

D-34109 Kassel

Germany 
